\title{
PEMBERIAN ENZIM LIGNOSELLULOSA DALAM PAKAN BUATAN TERHADAP PERTUMBUHAN DAN TINGKAT KELULUSHIDUPAN BENIH IKAN GURAMI (Osphronemus gouramy Lac.)
}

\section{THE GRANTING OF AN ENZYME LIGNOSELLULOSA IN FEED ARTIFICIAL ON THE GROWTH AND THE SURVIVAL RATE SEED GOURAMI (Osphronemus gouramy Lac.)}

\author{
Muhammad Yusuf Akbar, Agustono dan Rahayu Kusdarwati \\ Fakultas Perikanan dan Kelautan Universitas Airlangga \\ Kampus C Mulyorejo - Surabaya, 60115 Telp. 031-5911451
}

\begin{abstract}
Gurami having economic values of. Have abundance, namely able in waters with its oxygen relatively low. Belong to the species of carnivorous herbs herbivora. Unprofitableness is eat feed derived from herbs with content nutrition relatively low compared to animals, so it impact on its growth slow, easly diseases, easly stress, hard eat and SR low.

The purpose of this research isto know the addition of enzyme lignosellulase in artificialfeedincreased growth and increased survival rate seed gourami. Method research used is experimental with delightful random complete (RAL) with five treatment and four deuterenomy. The treatment used were : control (A), enzyme $550 \mathrm{ml}(\mathrm{B})$, enzyme $600 \mathrm{ml}(\mathrm{C})$, enzyme $650 \mathrm{ml}$ (D), and enzyme $750 \mathrm{ml}(\mathrm{E})$. The main parameters measured were growth rate, and survival rate. The supporting parameters observedwas water quality. Data analysis used analysis of variance (ANOVA) to know the effect of the treatments. To know the difference among treatments used Duncan's Multiple Range Test (DMRT).

The result showed that the provision of enzymes give a real power $(\mathrm{p}<0.01)$ against growth rate daily and growth long absolute gourami (Osphronemus gouramy) To survival rate and feed conversion ratio gourami give impact which is not dissimilar real. Growth best on treatment $\mathrm{E}(0.0214)$, then successive followed by treatment D (0.0174), C (0.015), B (0.0142) and A (0.0128). Conversion ratio feed on all treatment e 10,415, that is, e then successive followed by treatment $d(12,915), c(14,3975), b$ $(15,6375)$ and a $(17,5325)$. Survival rate obtained $100 \%$. Water quality media maintenance gourami is temperature $26^{\circ} \mathrm{C}-29^{\circ} \mathrm{C}, \mathrm{pH} 7-8$, oxygen dissolved $3.5-5 \mathrm{mg} / \mathrm{l}$ and ammonia $0.004-0.005 \mathrm{mg} / \mathrm{l}$.
\end{abstract}

Keywords : Osphronemus gouramy, growth, survival rate, enzyme

Pendahuluan

Gurami memiliki nilai ekonomis tinggi. Mempunyai kelebihan, yaitu mampu dalam perairan dengan kondisi oksigen yang relatif rendah (Susanto, 2000). Termasuk ke dalam jenis ikan pemakan tumbuh-tumbuhan atau herbivora (Puspowardoyo dan Siregar, 1992). Selain itu menurut Sitanggang (1995), termasuk omnivora atau pemakan sumber nabati dan hewani.

Kelemahannya adalah pertumbuhannya yang lambat, mudah terserang penyakit, mudah stress, susah makan dan survival rate rendah (Susanto, 2000). Gurami mudah terserang penyakit maka akan mempercepat terjadinya kematian sehingga survival ratenya rendah. Faktor penyebab penyakit pada ikan adalah stress, kekurangan gizi, pemberian pakan yang berlebihan, luka, kualitas air. Dengan bantuan enzim lignosellulase dalam pakan akan mempercepat reaksi kimia yang menghasilkan senyawa ATP dan senyawa-senyawa lain yang berenergi tinggi seperti pada proses respirasi, fotosintesis, kemosintesis, sintesis protein, dan lemak dimana dapat mengurangi kematian dan SR tinggi (Puspaningsih dan Lamid, 2009)

Pakan dengan penggunaan enzim lignosellulase telah diuji pada benih ikan gurami (Osphronemus gouramy. Lac.), didapatkan hasil bahwa pakan dengan penambahan Enzim Lignosellulase dosis $700 \mathrm{ml} / \mathrm{kg}$ pada pakan memiliki laju pertumbuhan yang tinggi yaitu 1,3-1,7 g/minggu, jika dibandingkan dengan kontrol (tanpa penambahan Enzim Lignosellulase dalam pakan) yaitu 1-1,2 g/minggu. Maka perlu dilakukan penelitian tentang pengaruh penambahan Enzim Lignosellulase dalam pakan terhadap pertumbuhan dan tingkat kelulushidupan benih ikan gurami (Osphronemus gouramy. Lac.).

Tujuan dari penelitian ini adalah untuk Mengetahui penambahan enzim lignosellulase 
dalam pakan buatan terhadap peningkatam pertumbuhan benih ikan gurami dan Mengetahui penambahan enzim lignosellulase dalam pakan buatan terhadap peningkatan kelulushidupan benih ikan gurami.

\section{Metodologi}

Penelitian ini dilakukan di Fakultas Perikanan dan Kelautan, Universitas Airlangga. Analisis proksimat bahan baku pakan dilakukan di Laboratorium Pakan Ternak Fakultas Kedokteran Hewan, Universitas Airlangga, Surabaya. Waktu pelaksanaan penelitian pada tanggal 3 Agustus sampai dengan 7 Oktober 2012 .

Alat yang digunakan dalam penelitian ikan gurami adalah akuarium yang panjang $50 \mathrm{~cm}$, lebar $20 \mathrm{~cm}$ dan tinggi $20 \mathrm{~cm}$, selang penyipon, seser, timbangan digital, penggaris besi, $\mathrm{pH}$ meter, termometer, DO meter.

Bahan penelitian yang digunakan adalah benih ikan gurami, air tawar, pakan dan enzim.

Penelitian ini menggunakan Rancangan Acak Lengkap (RAL) dimana semua dikondisikan sama kecuali perlakuan (Kusriningrum, 2008). Perlakuan yang digunakan adalah 5 perlakuan dengan 4 kali ulangan. Hasil analisis proksimat pakan percobaan antar perlakuan yang diuji Layanan Pemeriksaan Laboratoris, Konsultasi dan pelatihan Fakultas Kedokteran Hewan, Universitas Airlangga adalah perlakuan A 31,24, B 34,7, C 36.77, D 35,27 dan E 40,52.

Media pemeliharaan yang digunakan dalam penelitian ini adalah air tawar. Air tersebut ditempatkan kedalam 20 bak. Tiap bak diisi air dengan volume 20 liter. Sebelum dilakukan penebaran benih ikan gurami, terlebih dahulu air disterilisasi dengan filterisasi selama tiga hari.

Semua peralatan yang akan digunakan dalam penelitian juga disterilisasi terlebih dahulu dengan menggunakan klorin 400 ppm kemudian dibilas dengan menggunakan air bersih kemudian dibilas dengan air bersih dan dikeringkan (BBL, 2003). Tujuan sterilisasi alat dan media pemeliharaan adalah agar organism penyebab penyakit dapat dimusnahkan dan kotoran serta senyawa beracun dapat dinetralkan (Afrianto danLiviawaty, 1992)

Parameter utama dalam penelitian adalah pertumbuhan dan tingkat kelulushidupan benih ikan gurami. Parameter pendukung dalam penelitian adalah suhu, $\mathrm{pH}$, dan oksigen terlarut. Pemberian enzim lignosellulase dalam pakan buatan terhadap pertumbuhan dan tingkat kelulushidupan benih ikan gurami (Osphronemus gouramy Lac.) dianalisis dengan menggunakan analisis varian (ANAVA) dengan uji lanjutan menggunakan uji jarak berganda Duncan (Kusriningrum, 2008).

\section{Hasil dan Pembahasan}

Data rata-rata laju pertumbuhan harian terdapat pada Tabel 1. Hasil uji statistik menunjukkan bahwa perlakuan pemberian enzim lignosellulase menghasilkan laju pertumbuhan benih ikan gurami perbedaan yang sangat nyata $(p<0,01)$ sehingga dilanjutkan dengan Uji Jarak Berganda Duncan.

Laju pertumbuhan harian berfungsi untuk menghitung persentase pertumbuhan berat ikan per hari. Hasil perhitungan statistik menunjukkan pemberian enzim pada masingmasing perlakuan dengan kandungan energi 3291.59 - $3350.53 \mathrm{Kcal} / \mathrm{kg}$ dan protein sebesar 31.24 - 40.52 mempengaruhi laju pertumbuhan harian ikan gurami $(\mathrm{p}<0,05)$. Laju pertumbuhan harian pada perlakuan E(7.08) dengan pemberian enzim $700 \mathrm{ml}$ lebih tinggi daripada perlakuan $\mathrm{B}(3.68)$ dengan pemberian enzim 550ml. Menurut Santoso (2010) beberapa enzim dapat bekerja bersama dalam urutan tertentu, dan menghasilan lintasan metabolisme. Dalam lintasan metabolisme, satu enzim akanmembawa produk enzim lainnya sebagai substrat. Setelah reaksi katalitik terjadi, produk kemudian dihantarkan ke enzim lainnya. Kadang-kadang lebih dari satu enzim dapat

Tabel 1. Hasil Laju Pertumbuhan Harian Ikan Gurami

\begin{tabular}{|c|c|c|}
\hline Perlakuan & Laju Pertumbuhan (g/hari) & Transformasi $\sqrt{\mathrm{y}}$ \\
\hline A & $0,0128 \pm 0,00155$ & $0,1128^{\mathrm{b}} \pm 0,00691$ \\
$\mathrm{~B}$ & $0,0142 \pm 0,00119$ & $0,1190^{\mathrm{b}} \pm 0,00500$ \\
C & $0,015 \pm 0,00132$ & $0,1223^{\mathrm{b}} \pm 0,00605$ \\
D & $0,0174 \pm 0,00270$ & $0,1318^{\mathrm{b}} \pm 0,00987$ \\
E & $0,0214 \pm 0,00102$ & $0,1463^{\mathrm{a}} \pm 0,00351$ \\
\hline
\end{tabular}

${ }^{\mathrm{a}, \mathrm{b}}$ : Superskrip yang berbeda pada kolom yang sama menunjukkan terdapat perbedaan yang sangat nyata $(\mathrm{P}<0,01)$ 
Tabel 2. Kisaran Kualitas Air Pemeliharaan

\begin{tabular}{|c|c|c|c|c|c|}
\hline Parameter & Perlakuan A & Perlakuan B & Perlakuan C & Perlakuan D & Perlakuan E \\
\hline Suhu $\left({ }^{\circ} \mathrm{C}\right)$ & $26-29$ & $26-29$ & $26-29$ & $26-29$ & $26-29$ \\
$\begin{array}{c}\text { Oksigen terlarut } \\
(\mathrm{mg} / \text { liter })\end{array}$ & $3,5-5$ & $3,5-5$ & $3,5-5$ & $3,5-5$ & $3,5-5$ \\
$\mathrm{pH}$ & $7-8$ & $7-8$ & $7-8$ & $7-8$ & $7-8$ \\
Amonia (mg/liter) & 0,004 & 0,005 & 0,005 & 0,005 & 0,005 \\
\hline
\end{tabular}

mengatalisasi reaksi yang sama secara bersamaan.

Data rata-rata tingkat kelulushidupan ikan gurami yang diberi enzim lignosellulase yang dicampur pada pakan. Hasil uji statistik menunjukkan bahwa perlakuan pemberian enzim lignoselluase $550 \mathrm{ml} / \mathrm{kg}, 600 \mathrm{ml} / \mathrm{kg}, 650$ $\mathrm{ml} / \mathrm{kg}$ dan $700 \mathrm{ml} / \mathrm{kg}$ menghasilkan tingkat kelulushidupan yang tidak berbeda nyata ( $p>0,05)$ sehingga tidak dilanjutkan uji jarak berganda Duncan.

Masing-masing perlakuan menghasilkan tingkat kelulushidupan sebesar $100 \%$. Hal ini membuktikan bahwa pakan yang dicampur enzim yang dipelihara dengan padat penebaran 2,5 gram/liter mampu memberikan energi yang dapat dimanfaatkan oleh ikan gurami untuk pemeliharaan dan aktivitas tubuh sehingga ikan dapat meneruskan hidupnya. Penelitian yang dilakukan oleh Sulistomo (2008) dengan perlakuan pemberian pakan berupa T.tubifex yang dipelihara dengan padat penebaran $\quad 0,75 \mathrm{gram} / \mathrm{liter}$ menghasilkan kelulushidupan $81,43 \%$. Dengan demikian penelitian dengan pemberian pakan buatan, pakan alami dan kombinasinya yang dipelihara dengan kepadatan 0,15 gram/liter lebih baik karena tingkat kelulushidupan yang dihasilkan dapat mencapai $100 \%$ selama 42 hari.

Data nilai kisaran kualitas air penelitian dapat dilihat pada tabel 2 .

Suhu selama penelitian berkisar antara $26-29^{\circ} \mathrm{C}$.Kisaran ini tidak layak untuk ikan gurami.Suhu Lingkungan yang baik untuk pertumbuhan ikan gurami berkisar antara 26-28 ${ }^{0} \mathrm{C}$ (Sitanggang dan Sarwono, 2006).Suhu air pada pemeliharaan pada penelitian ini sudah memenuhi syarat bagi kehidupan ikan gurami.

Oksigen terlarut selama penelitian berada dalam kisaran 3,5-5,8 mg/l. Menurut Susanto (2000), oksigen minimal yang dibutuhkan oleh ikan guramiyaitu harus lebih dari3,0 mg/l. Dengan demikian oksigen terlarut pada pemeliharaan ikan gurami memenuhi persyaratan.

Hasil pengukuran $\mathrm{pH}$ menunjukkan kisaran antara 7-8. Bahwa $\mathrm{pH}$ pemeliharaan ikan gurami berkisar antara 7-8 (Puspowardoyo dan Djarijah, 1992). Dengan demikian kisaran $\mathrm{pH}$ pada pemeliharaan ikan gurami masih memenuhi persyaratan karena $\mathrm{pH}$ tidak berpengaruh langsung terhadap ikan gurami tetapi pada reaksi kimia dalam air.

Ammonia selama penelitian berada pada angka 0,004 - $0.005 \mathrm{mg} / \mathrm{l}$. Menurut Yovina (2010) bahwa kadar ammonia terukur yang dapat menyebabkan kematian adalah lebih dari $1 \mathrm{ppm}$ (1 $\mathrm{mg} / \mathrm{l})$. Dengan demikian kandungan ammonia pada pemeliharaan ikan gurami masih memenuhi persyaratan.

\section{Daftar Pustaka}

Afrianto, E dan E. Liviawaty.1992. Pengendalian Hama dan Penyakit Ikan. Kanisius. Jakarta. hal. 33.

Balai Budidaya Laut (BBL). Direktorat Jenderal Perikanan Budidaya Departemen Kelautan Dan Perikanan. 2003. Penanganan Penyakit Ikan Budidaya Laut. ISBN : 979-98017-1-0. No : 12. Lampung. hal. 24.

Kusriningrum, R. S. 2008. Perancangan Percobaan. Universitas Airlangga. Surabaya. hal. 43-63.

Puspaningsih, N.Y.T. dan Lamid. M. 2009. Aplikasi Enzim dalam Campuran Pupuk Organik.

Puspowardoyo, H dan A. S. Djarijah.1992. Membudidayakan Gurami Secara Intensif. Kanisius.Yogyakarta.Hal.3154.

Santoso. 2010. Modul Enzimologi Seri Buku Kuliah Biokimia Kedokteran 1.2011

Sitanggang dan sarwono. 2006. Budidaya Gurami. Penebar Swadaya. Jakarta. Hal 9-23 
Pemberian EnzimLignosellulosa......

Sulistomo, B. H. 2008. Pengaruh Pemberian Kombinasi Pakan Buatan Dengan Daun Talas (Colocosia esculenta) yang Difermentasi Kombucha Terhadap Pertumbuhan Ikan Gurami

Susanto, H. 2000. Budidaya IkanGurame. Kanisius.Yogyakarta.Hal. 5-20
Yovina.2010. Pengaruh Penambahan Enzim Pada Pakan Buatan Terhadap Pertumbuhan dan Rasio Konversi Pakan Ikan Lele Dumbo (Clarias sp.) 